\title{
CONTRASTIVE STUDY OF ENGLISH AND UZBEK PUNCTUATION RULES
}

\author{
Madinabonu Rakhmon qizi Najmiddinova
}

Student Faculty of Foreign Philology, Department of English philology National University of Uzbekistan named after Mirza Ulugbek Tashkent, Uzbekistan

\section{Shakhnoza Mukhamedjanovna Jalolova}

Doctor of philosophy (PhD) of philological sciences, Associate professor National University of Uzbekistan

\section{ABSTRACT}

This article provides a comparative view of the use of punctuation in English and Uzbek, and explores the similarities and differences between them. There are also some ideas on how to use punctuation effectively and correctly. However, given that punctuation is one of the most important aspects of written and spoken speech, it is emphasized that their proper use will provide effective results not only for English linguists, but also for translators and grammar experts.

KEYWORDS:- Comparative typology, contrastive linguistics, punctuation, the full stop, the comma, the hyphen, the inverted commas, the semi-colon, the colon, parentheses.

\section{INTRODUCTION}

Comparative Linguistics or Comparative Grammar is a study of the relationships or correspondences between two or more languages and the techniques used to discover whether the languages have a common ancestor. Comparative grammar was the most important branch of linguistics in the 19th century in Europe. The study was originally stimulated by the discovery by Sir William Jones in 1786 that Sanskrit was related to Latin, Greek and German [1]. The need for further research in this field is increasing day by day with the rising interest in learning languages. Languages may share some common structures which will be easy to master for the learner. However, some features in languages are extinct and unique. This is especially true with the grammar where rules vary according to the root and family of a language.

\section{THE MAIN RESULTS AND FINDINGS}

Comparative typology is a branch of linguistics comparing languages to establish their similarities and differences. Its object is not singular and individual cases of similarity and difference, but those which are common for large groups of language elements. Comparative typology classifies languages according to their structure [2]. Present-day Comparative Linguistics has been developing in compliance with new modern research paradigms, under the influence of which it has undergone radical 
changes.

Comparative typology is a field of linguistics that studies and classifies languages according to their structural and functional features. Its aim is to describe and explain the common properties and the structural diversity of the world's languages. According to William Croft's book "Typology and Universals", the term "typology" is roughly synonymous with "taxonomy" classification and given the following definition: From an etymological point of view, the word typology consists of two Greek morphemes: typos means "type" and logos means "science" [3, P. 5].

As it is known, it is almost impossible to imagine a paragraph without any periods or commas. In truth this kind of sentence would be almost unreadable. Here is the proof why punctuation is very important.

- Definition of punctuation from Encyclopedia Britannica "the use of spacing, conventional signs, and certain typographical devices as aids to the understanding and correct reading, both silently and aloud, of handwritten and printed texts"

- The usage of punctuation is to help the reader understand the message. In speech: stress, intonation and pauses present a role of punctuation.

- A system specific to written language: a pause in spoken language - not always a punctuation mark punctuation imposes a more rigid structure to writing.

- $\quad$ There are 14 punctuation marks in English grammar and, at minimum, one of them has to appear in every sentence. However, in Uzbek language there are 10 punctuation marks which are used in a great variety.

\section{Names of punctuation marks}

Before looking at punctuation mark and defining their rule of usage we have to know about the names of punctuation marks.
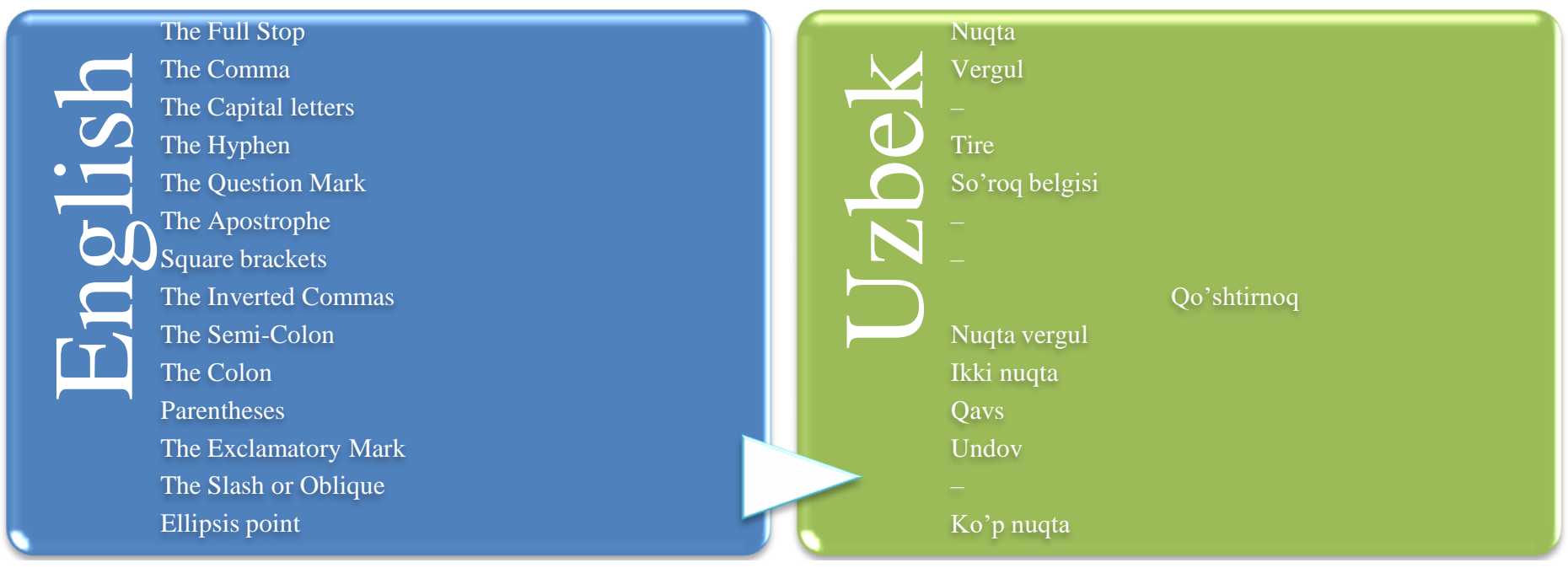
CURRENT RESEARCH JOURNAL OF PEDAGOGICS 2(6): 01-05, June 2021

DOI: https://doi.org/10.37547/pedagogics-crjp-02-06-01

ISSN 2767-3278

(C)2021 Master Journals

\section{Crossref do) 81 Google}

Accepted 04thJune, 2021 \& Published 09th June, 2021

Capital letters and full stop

In English capital letters are used to mark the beginning of a sentence and full stops to mark the end of a sentence. Capital letters are used at the beginning of proper nouns. Proper nouns include personal names (including titles before names), nationalities and languages, days of the week and months of the year, public holidays as well as geographical places: They are performing Beethoven's Sixth Symphony.

In addition to closing sentences, full stops are also used in initials for personal names: David A. Johnston, Accountant. Full stops are also used after abbreviations, although this practice is becoming less common: Dr. (doctor), etc. (etcetera) [4]. Although capital letters are used for same purpose, they are not punctuation mark.

Full stop in the Uzbek language is used at the end of sentence: Xalqimizning birligi, jipsligi bizning boyligimizdir.

Especially, in the imperative, and in nominative sentences if they are not expressing exclamation: Shunday harakat qilingki, birovga yuk bo'lmang, balki hamroh bo'ling. Ilk bahor. Daraxtalar endi kurtak yoza boshlagan palla.

Punctuation: question marks (?) and exclamation marks (!)

Question marks in English are used to make clear that what is said is a question. When we use a question mark, we do not use a full stop: Why do they make so many mistakes? [4].

In Uzbek question mark is used for more range options: at the end of question sentences: Navoiyning tilshunoslikka oid qanday asarlari bor? After question pronouns: Ot kim? Nima? Qayer? so'roqlariga javob bo'ladi and if there is misunderstanding sentence or word in the text or in sentence, question mark is put with parentheses: A.Qodiriyning "O'tkan kunlar" qissasida (?) o'zbek xalqining yaqin o'tmishi ifodalangan.

Exclamation marks in English are used to indicate an exclamative clause or expression in informal writing. When we want to emphasize something in informal writing, we sometimes use more than one exclamation mark: Listen! [4].

In Uzbek exclamation mark is used as same as in English: $\mathrm{Bu}$ yerning tabiati naqadar go'zal! Something which is different from English is that some words expressing excuse, greeting, agreement and others also come with exclamation marks: Ey! Hoy! Hop!

Punctuation: commas (,)

Commas in English are used to separate a list of similar words or phrases: It's important to write in clear, simple, accurate words.

We do not normally use a comma before and at the end of a list of single words: They travelled through Bulgaria, Slovakia, the Czech Republic and Poland. American English does use a comma in lists before: We took bread, cheese, and fruit with us. We use commas to separate words or phrases that mark where the voice would pause slightly: We had, in fact, lost all of our money. When main clauses are separated by and, or, but, we don't normally use a comma if the clauses have the same subject: They were very friendly and invited us to their villa in Portugal (Same subject). However, we sometimes use commas if the clauses have different subjects: It was an expensive hotel in the center of Stockholm, but we decided it was worth the money. When a subordinate clause comes before the main clause, we commonly use a comma to separate the clauses. However, we do not always do this in short sentences: If you get lost just phone us. When we use subordinate or non-finite comment clauses to give further details or more information, we commonly use commas to separate the clauses: To be honest, I thought they were very rude. We use commas to mark non- 
CURRENT RESEARCH JOURNAL OF PEDAGOGICS 2(6): 01-05, June 2021

DOI: https://doi.org/10.37547/pedagogics-crjp-02-06-01

ISSN 2767-3278

(C)2021 Master Journals

\section{Crossref do) 81 Google}

Accepted 04th June, 2021 \& Published 09th June, 2021

defining clauses. Such clauses normally add extra, non-essential information about the noun or noun phrase: The ambulance, which arrived after just five minutes, took three people to the hospital immediately [4].

In Uzbek commas are used in same ways with the exception of cohesive proposal sentences: Ilm ham, ijod ham bahs bilan tirik. Examples for other sentences where comma is used: Soy bo'yida odamlar gavjum joyda, sayil boshlandi. Ey Navoiy, boda birla xurram et ko'ngling uyin. Voy, namuncha ochilib ketibsan?

Moreover, another difference is when we are using reported speech in Uzbek language we use comma after the writers or speakers sentence: "Ko'ngil maxzanining qulfi til"- degan edi Hazrat Navoiy.

Punctuation: colons (:) and semi-colons (;) quotation marks ('...' or “...”), dashes (-)

Colons in English are used to introduce lists: There are three main reasons for the success of the government: economic, social and political. We also use colons to indicate a subtitle or to indicate a subdivision of a topic: Life in Provence: A Personal View. Also to introduce direct speech: Then he said: 'I really cannot help you in any way'.

Quotation marks in English are '...' or “...". In direct speech, we enclose what is said within a pair of single or double quotation marks, although single quotation marks are becoming more common. Direct speech begins with a capital letter and can be preceded by a comma or a colon: She said, "Where can we find a nice Indian restaurant?" or (She said: 'Where can we find a nice Indian restaurant?') We also use single quotation marks to draw attention to a word. We can use quotation marks in this way when we want to question the exact meaning of the word: I am very disappointed by his apology. I don't think he meant it at all.
We use semi-colons instead of full stops to separate two main clauses. In such cases, the clauses are related in meaning but are separated grammatically: Spanish is spoken throughout South America; in Brazil the main language is Portuguese. Semi-colons are not commonly used in contemporary English. Full stops and commas are more common [4].

In Uzbek colons are used when a sentence is finished structurally but by meaning it is still continuing: Ishlar vaqtida bajarilishi kerak: vaqtida bajarilmagan ish sust bo'ladi. Other ways of usage of colons are the same.

Semi-colons in Uzbek are used when two clauses are related by meaning rather than grammatically: Yutib chiqish uchun ot chopqir, zotdor bo'lishi va yaxshilab toblanib sovutilishi; chavandoz usta, epchil bo'lishi kerak.

In Uzbek quotation marks are widely used in reported speech, names of novels, names of magazines and newspapers, all given names to places, plays, transports, idioms, names of group of plants. Dashes are more common in informal writing. They can be used in similar ways to commas or semi-colons. Both single and multiple dashes may be used: Our teacher - who often gets cross when we're late - wasn't cross at all. No one could believe it!

In Uzbek there is only hyphen and it is used as dashes and as hyphen: Kitob - eng yaqin do'stimiz.

Brackets

In English there are three types of brackets: (...), $[\ldots]$ and $\{\ldots .$.$\} . However, in Uzbek only round$ brackets - parentheses (...) are used as a punctuation mark.

\section{Conclusion}

In conclusion, punctuation is essential, and is used to convey and clarify the meaning of 
CURRENT RESEARCH JOURNAL OF PEDAGOGICS 2(6): 01-05, June 2021

DOI: https://doi.org/10.37547/pedagogics-crjp-02-06-01

ISSN 2767-3278

(C)2021 Master Journals

Crossref dof 81 Google

Accepted 04thJune, 2021 \& Published 09th June, 2021

written language. It is such simple marks as the full stop or the comma, and the more complex ones of semicolons and hyphens. Getting punctuation wrong can change the entire meaning of a sentence. Therefore, in this article almost all punctuation marks are described with details to make aware people from mistakes they may make while speaking, writing or translating.

\section{REFERENCES}

1. Encyclopedia of Britannica - Add new Web site: Fact Monster - Society - Comparative Linguistics.- Swati Chopra Nov 23, 2011. Article added to new online database- The Editors of Encyclopaedia Britannica July 20, 1998

https://www.britannica.com/science/com parative-linguistics

2. Presentation by Aziza Musoeva. (2019 May) Comparative typology in English and Uzbek languages. Samarkand State Institute of Foreign Languages https://www.researchgate.net/publication /333324822

3. Rasulova. M.I.,.Shukurova. Z.I Comparative typology of English, Uzbek and Russian languages. (2017) Tashkent (p 260)

4. https://dictionary.cambridge.org/gramma r/british-grammar/punctuation-

Cambridge dictionary 